\title{
Adsorption of Ciprofloxacin Hydrochloride from Aqueous Solution by Iraqi Porcelinaite Adsorbent
}

\author{
Dhafir T. Ajeel Al-Heetimi, Muna Abdul Rasool Kadhum and Omar S. Alkhazrajy \\ Department of Chemistry, College of Education for Pure Science Ibn -Alhaitham, University of \\ Baghdad, Baghdad-Iraq. \\ E-mail: dhafir73 @ yahoo.com.
}

\begin{abstract}
Pharmaceuticals are widely distributed in different applications and also released into the environment. Adsorption of Ciprofloxacin $\mathrm{HCl}(\mathrm{CIPH})$ on Porcelinaite was studied at ambient conditions. The adsorption isotherms can be well described using the Freundlich and Temkin equations. The $\mathrm{pH}$ of the solution influences significantly the adsorption capacity of Porcelinaite, the adsorption of CIPH increased from the initial $\mathrm{pH} 1.3$ and then decreased over the $\mathrm{pH}$ rang of 3.8-9. The adsorption is sensitive to the change in ionic Strength, which indicate that electrostatic attraction is a significant mechanism for sorption process. The enthalpy change $(\Delta \mathrm{H})$ for the adsorption of CIPH onto Porcelinaite signifies an endothermic adsorption. The $\Delta \mathrm{G}$ value is negative at all studied temperatures, inferring that, the adsorption of CIPH onto porcelinaite will follow a spontaneous trend. The $\Delta \mathrm{G}$ value decreased when the temperature increased from $15^{\circ} \mathrm{C}$ to $37.5^{\circ} \mathrm{C}$, suggesting increase in adsorption of CIPH with increasing temperature. The positive value of $\Delta \mathrm{S}$ reflects the affinity of porcelinaite towards drug and also suggests increased randomness at the solid-solution interface.
\end{abstract}

Keywords: Adsorption, Ciprofloxacin $\mathrm{HCl}$, Freundlich and Temkin isotherms, Porcelinaite, Thermodynamic parameters.

\section{Introduction}

The impact and removal of conventional pollutants, such as persistent organic pollutants was in focus for the last decades and so their behavior is well understood [1]. On the other side very little is known about the behavior of trace pollutants yet, which are present in the environment in extremely low concentrations.

Pharmaceuticals are an example for the variety of man-made trace pollutants that are introduced in surface or subsurface water bodies [2]. Pharmaceuticals have been identified in the environment, including antibiotics, analgesics, psychiatric drugs, and natural and synthetic hormones [3]. Unused human pharmaceuticals may also enter the environment through landfill leachate [4-7].

Many types of adsorbents such as kaolin [8,9], charcoal [10], polymers [11] attapuligate [12] and bentonite [13-17] in adsorption of drug, are recognized in clinical practice and environmental treatment. The safety, high adsorptive capacity, there low density and the high specific surface, have been accepted for a long time, and they account for most of the current uses of clay.
Pharmaceuticals poisoning also has been defined as a condition produced by any substance which when swallowed, inhaled, injected or absorbed precutaneously is capable of causing death, injury, toxic or untoward reactions [18].

Ciprofloxacin hydrochloride is a synthetic chemotherapeuticantibiotic (1-cyclopropyl-6fluoro-1,4-dihydro-4- oxo-7-(1-piperazinyl)-3quinoline carboxylic acid), Its empirical formula is $\mathrm{C}_{17} \mathrm{H}_{18} \mathrm{FN}_{3} \mathrm{O}_{3}$ and its molecular weight is $331.4 \mathrm{~g} / \mathrm{mol}$ Fig.1, Ciprofloxacin hydrochloride is a broad-spectrum antimicrobial agents belonging to the fluoroquinolone group Its mode of action depends upon blocking bacterial DNA replication by binding itself to an enzyme called DNA gyrase, thereby preventing the enzyme's ability to untwist the DNA double helix, which is required for DNA replication [19]. 


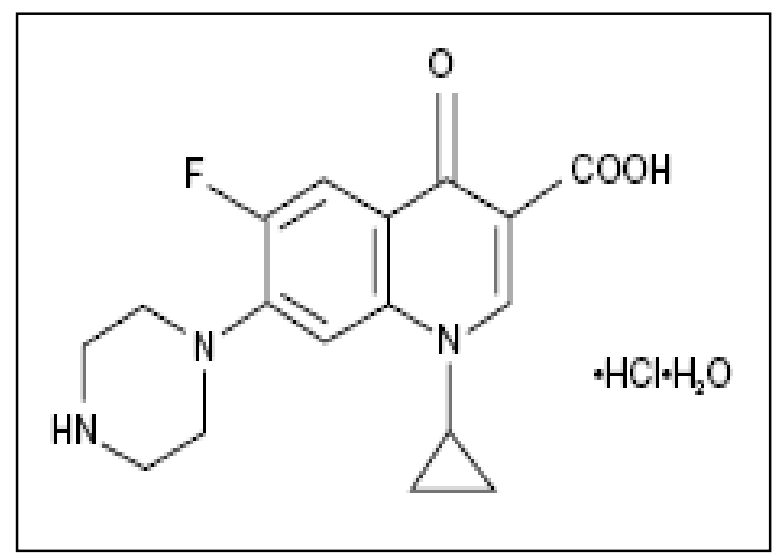

\section{Fig. (1) Formula of Ciprofloxacin Hydrochloride.}

The adsorption capacity of ciprofloxacin hydrochloride (CIPH) was determined on three types of carbon-based materials: activated carbon (commercial sample), carbon nanotubes (commercial multi-walled carbon nanotubes) and carbon xerogel [20]. also studied adsorption capacities on montmorillonite, rectorite, and illite [21], charcoal and talc [22], Chitosan [23]. Various studies have shown that CIPH is susceptible to direct photochemical transformations by exposure to direct ultraviolet (UV) light and by adding photocatalytic reagents such as hydrogen peroxide $\left(\mathrm{H}_{2} \mathrm{O}_{2}\right)$, and titanium dioxide $\left(\mathrm{TiO}_{2}\right)$, to aqueous solutions [24].

In this study for the first time we investigate the adsorption of Ciprofloxacin Hydrochloride on the surface of Iraqi porcelinaite. The system variables studied include sorbent dose, contact time, FTIR analysis, initial concentration of the drug, $\mathrm{PH}$, ionic strength and temperature.

\section{Experimental Process}

\section{Materials and apparatus}

The drug employed in this research (Ciprofloxacin Hydrochloride) was obtained from (state company for drug industries and (porcelinaite) employed in this study were obtained from open mine in area of the western desert- Iraq supplied from (The general company for Geological survey and mining), Baghdad, The mineralogical composition of the adsorbent is shown in the Table (1). Sodium Chloride (fluka) and Hydrochloric acid (BDH). The clay in powder forms were washed several times with excessive amounts of distilled water. The adsorbent were dried at $\left(120{ }^{\circ} \mathrm{C}\right)$ in an oven (D-6450) hand $\left(160{ }^{\circ} \mathrm{C}\right)$ for $3 \mathrm{~h}$ and then kept in airtight containers. The clay was then ground and sieved by using a test sieves (Retsoh Gmb\& Co. KG, Germany) sieve. The particle size of $75 \mu \mathrm{m}$ was used for the clay in the experiments of this work, Thermostated shaker bath (Lab tech-Korea), $\mathrm{pH}$ meter (HI98107, Hanna Instruments) then filtered by using filter paper Wattman No. 42 and centrifuge(Hettich EBA20) The spectrophotometric absorbencies did by (SHIMADZU 1800) double beam UV- Visibspectrophotometer, FTIR, IR Affinity (SHIMADZU, Japan).

Table (1)

Chemical composition of Iraqi Porcelinaite minerals.

\begin{tabular}{|c||c|}
\hline Element & \% wt. \\
\hline \hline $\mathrm{O}_{\text {(total })}$ & 44.55 \\
\hline $\mathrm{Si}$ & 25.04 \\
\hline \hline $\mathrm{Fe}$ & 0.30 \\
\hline $\mathrm{Al}$ & 0.77 \\
\hline \hline $\mathrm{Ca}$ & 4.29 \\
\hline \hline $\mathrm{Ti}$ & 0.07 \\
\hline \hline $\mathrm{Na}$ & 12.97 \\
\hline \hline $\mathrm{L}$ O.I & 12.00 \\
\hline \hline
\end{tabular}

\section{Methods}

Standard solution of Ciprofloxacin Hydrochloride drug made in distilled water by dissolving $1 \mathrm{gm}$ of drug in $1000 \mathrm{ml}$. UV-Visible scanning spectrum has been recorded and wavelength value corresponding to the maximum absorption found to be at $(275 \mathrm{~nm})$, this value utilized for measurements of estimation throughout this research. To determine adsorption isotherms for the drug with porcelinaite surface, solution of different concentrations for this drug were prepared by serial dilutions in the range of $(2-14 \mathrm{mg} / \mathrm{L})$. Adsorbent surface samples $0.1 \mathrm{~g}$ was weighed by using electrical balance. Each sample was then placed in a screw cap bottle and $10 \mathrm{ml}$ of serial drug solution was added to each sample. The bottles were put in thermo stated shaker at different temperature $\left(15,25\right.$ and $\left.37.5^{\circ} \mathrm{C}\right)$. The shaking was continued for a period exceeding the time to attain equilibrium for the adsorbents. The $\mathrm{pH}$ of solution was adjusted 
with $\mathrm{HCl}$ and $\mathrm{NaOH}$ solutions and ionic strengths $(0.2$, and $0.4 \mathrm{M}$ Sodium Chloride solution). At the end of the adsorption period, the rotation was stopped and the solution was filtered by using Filter paper then centrifuged. The clear supernatants were assayed for drug, spectrophotometrically. The adsorbed amount of the drug was calculated from the concentration in solutions before and after adsorption according to the equation (1):

$\mathrm{Qe}=\mathrm{x} / \mathrm{m}=(\mathrm{Co}-\mathrm{Ce}) \mathrm{V} / \mathrm{W}$

Where $\mathrm{Co}$ and $\mathrm{Ce}$ are the initial and equilibrium liquid-phase concentrations of drug solution(mg/L), respectively, $Q e$ is equilibrium drug concentration on adsorbent $(\mathrm{mg} / \mathrm{g}), \mathrm{V}$ is the volume of drug solution $(\mathrm{L})$, and $\mathrm{W}$ is the mass of clay sample used $(\mathrm{g})$.

The percentage of drug removal was determined using the equation (2):

\%removal $=\left(\mathrm{C}_{0}-\mathrm{C}_{\mathrm{e}}\right) \times 100 / \mathrm{C}_{\mathrm{o}}$

From the Beer's plot for the Ciprofloxacin Hydrochloride drug previously made, the amount of free drug in solution was determined. From the results, the time to attain equilibrium for adsorbent was determined.

\section{Result and Discussion}

\section{Effect of initial drug concentrations}

The adsorption capacity of porcelinaite for CIP was determined at different initial drug concentrations $(2-14 \mathrm{ppm})$. The results were represented in Fig. (2) show that the drug amount sorbed increase with the increase of drug concentration but the percent of drug removal decrease at high concentration. The increase in adsorption with the increase in CIP concentration is due to the driving force that initial concentration provides to overcome the mass transfer resistance between the aqueous and solid phases.

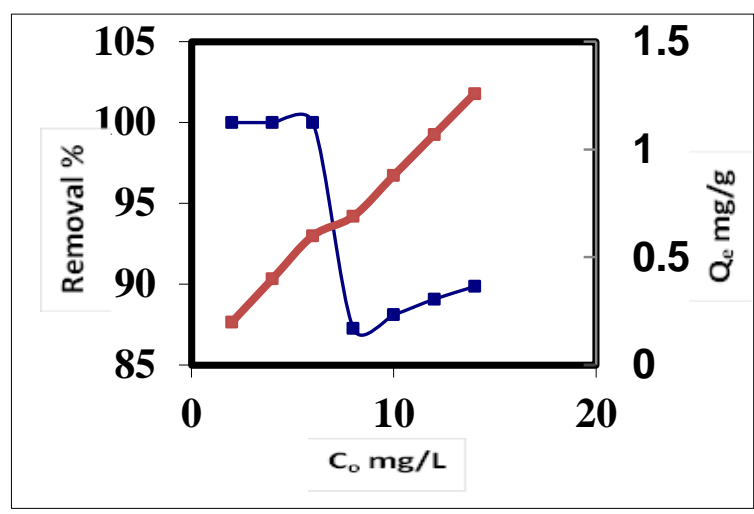

Fig.(2) The influence of initial drug concentration on the adsorption of CIPH on porcelinaite $(\mathrm{T}=37.5 \mathrm{Co}, \mathrm{pH}=3.8, \mathrm{P}$. size

$75 \mu \mathrm{m})$.

\section{Effect of adsorbent dose}

The dependence of adsorption of the drug on the amount of porcelinaite was studied by varying the adsorbent dose from 0.05 to $1 \mathrm{~g}$ at temperature $\left(37.5^{\circ} \mathrm{c}\right)$ and at their optimal $\mathrm{pH}$, while keeping the volume and concentration of the drug solution constant. The results are given in Table (2) and graphically represented in Fig. (3). The Fig. indicates that maximum sorption at $0.1 \mathrm{~g}$ and then there was no further increase of sorption. It is evident that the maximum removal of drug $84.716 \%$ at $10 \mathrm{mg} / \mathrm{L}$ concentration was obtained with $0.1 \mathrm{~g}$ of Porcelinaite. The adsorption of the drug decreased rapidly with increase in the dose of the adsorbent.

Table (2)

Effect of adsorbent dose on adsorption of CIPH at $10 \mathrm{mg} / \mathrm{L}$.

\begin{tabular}{|c||c||c||}
\hline Wt. $(\mathrm{g})$ & $C e(\mathrm{mg} / \mathrm{L})$ & Removal \% \\
\hline \hline 0.05 & 1.6133 & 83.867 \\
\hline \hline 0.1 & 1.5284 & 84.716 \\
\hline \hline 0.2 & 1.6860 & 83.140 \\
\hline \hline 0.3 & 1.7709 & 82.291 \\
\hline \hline 0.4 & 1.8193 & 81.807 \\
\hline 0.5 & 1.8921 & 81.079 \\
\hline \hline 0.6 & 1.9406 & 80.594 \\
\hline \hline 0.8 & 2.1466 & 78.534 \\
\hline \hline 1.0 & 2.2921 & 77.079 \\
\hline
\end{tabular}




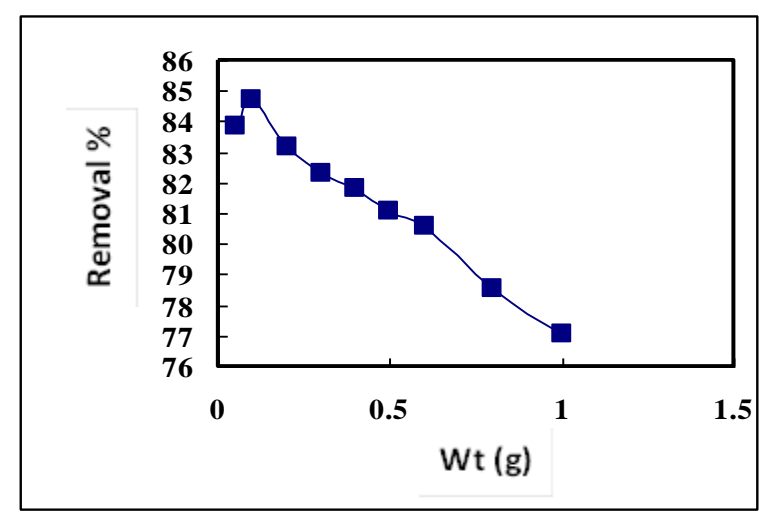

Fig. (3) Effect of adsorbent dose on adsorption of CIPH at $10 \mathrm{mg} / \mathrm{L}$.

\section{Effect of contact time}

The equilibrium time is one of the characteristics, defending efficiency in the removal of drug. The effect of contact time and the percent removal of drug form aqueous solution by porcelinaite is shown in the Fig. (4). It has been observed from the data that over $78.29 \%$ of the adsorption of drug form aqueous solution of porcelinaite was completed within first 5 minutes and equilibrium was reached at 20 minutes. In case of adsorption this was because of rapid diffusion of drug from solution to the external surface of adsorbents where the drug sorbs at the active surface of the adsorption.

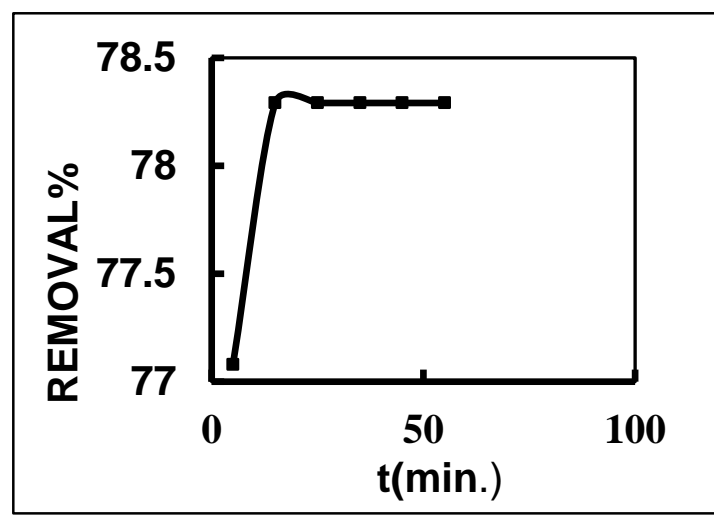

Fig.(4) Effect of contact time at $37.5^{\circ} \mathrm{C}$.

\section{FTIR analysis}

The FTIR spectrum obtained Fig. (5) for the adsorbent displayed the following major bands: $3630 \mathrm{~cm}^{-1}$ : Si-OH, Al-OH stretch; 3539.38-1637.56 $\mathrm{cm}^{-1}$ : H-OH stretch; $1637.56-1045 \mathrm{~cm}^{-1}: \mathrm{Si}-\mathrm{O}-\mathrm{Si}, \quad \mathrm{Si}-\mathrm{O} \quad$ stretch; $472 \mathrm{~cm}^{-1}: \mathrm{Si}-\mathrm{O}, \mathrm{Si}-\mathrm{O}-\mathrm{Fe}$ stretch It is reflecting the complex nature of adsorbent and shows significant band shifting and intensity changes due to ciprofloxacin hydrochloride sorption Fig. (5 and 6).

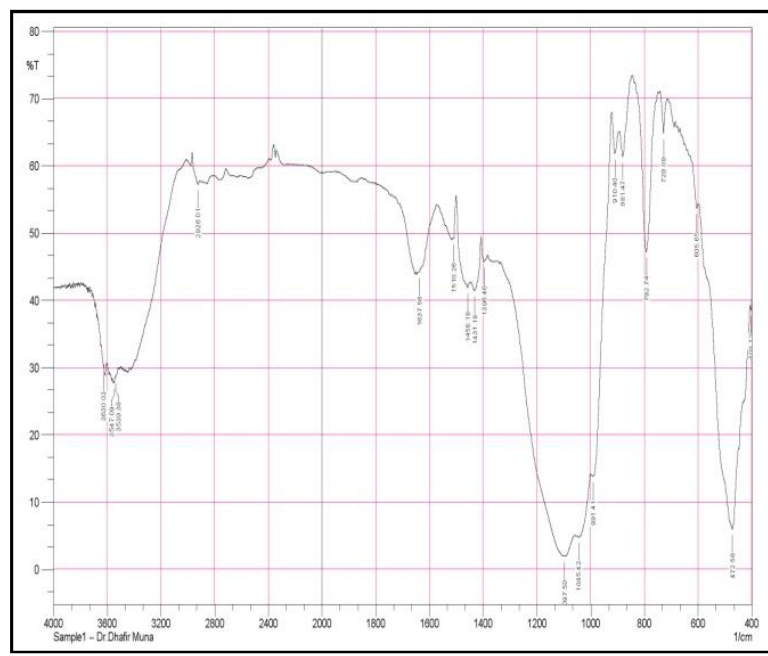

Fig. (5) FTIR spectrum of fresh Porcelinaite adsorbent.

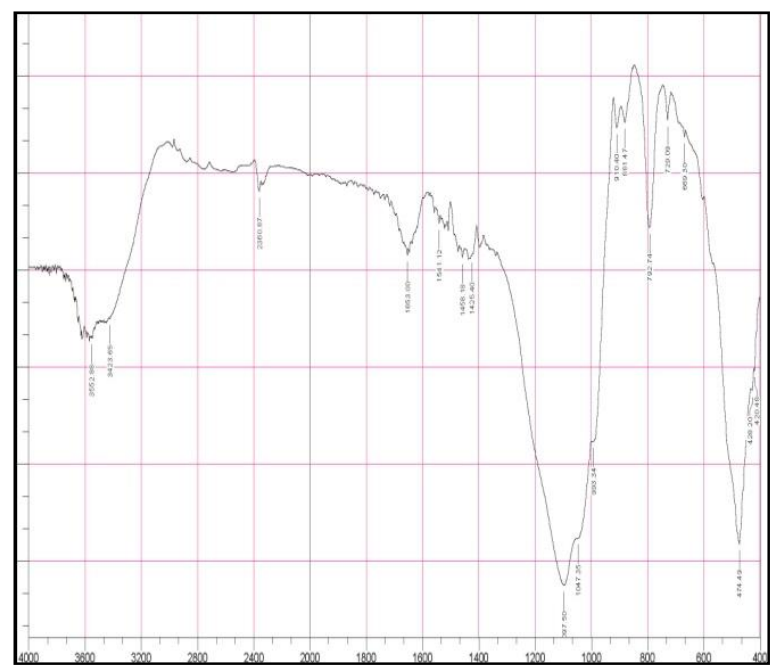

Fig. (6) FTIR spectrum of drug loaded adsorbent.

\section{Effect of pH on adsorption}

The $\mathrm{pH}$ is one of the important factors in controlling the adsorption of drug on adsorbent. The adsorption of CIPH from $10 \mathrm{mg} / \mathrm{L}$ concentration on given adsorbent was studied at $\mathrm{pH}(1.3,3.8,5,6,7$ and 9). The result shown in Table (3) Fig. (7) shows that the adsorption of CIP increased from the initial $\mathrm{pH}$ 1.3 and then decreased over the $\mathrm{pH}$ rang of 3.8-9.Therefore, In this study we found that $\mathrm{pH}(1.3$ )as the optimum $\mathrm{pH}$. At low $\mathrm{pH}$ region the surface of the clay will be largely protonated. The positive ions $(\mathrm{H}+)$ provide an electrostatic attraction between the clay surface and the drug molecules leading to maximum adsorption on the other hand, at $\mathrm{pH}$ 
above 1.3 the degree of protonation of The surface of the clay will be less which result in the decrease in diffusion and adsorption thereby due to electrostatic repulsion Furthermore, lower adsorption of the Drug molecules in alkaline medium can be attributed to the competition from excess Hydroxide ions $\left(\mathrm{OH}^{-}\right)$with the drug molecules for the adsorption sites.

\section{Table (3)}

Effect of pH on adsorption of CIP at $10 \mathrm{mg} / \mathrm{L}$.

\begin{tabular}{|c||c|c||c|}
\hline$p \boldsymbol{p H}$ & $\boldsymbol{C e}(\boldsymbol{m g} / \mathbf{L})$ & $\boldsymbol{C o}-\mathrm{Ce}$ & Removal\% \\
\hline \hline 1.3 & 0 & 10 & 100 \\
\hline 3.8 & 1.189 & 8.811 & 88.11 \\
\hline 5 & 1.286 & 8.714 & 87.14 \\
\hline 6 & 1.4072 & 8.5928 & 85.928 \\
\hline 7 & 1.6012 & 8.3988 & 83.988 \\
\hline 9 & 1.8315 & 8.1685 & 81.685 \\
\hline
\end{tabular}

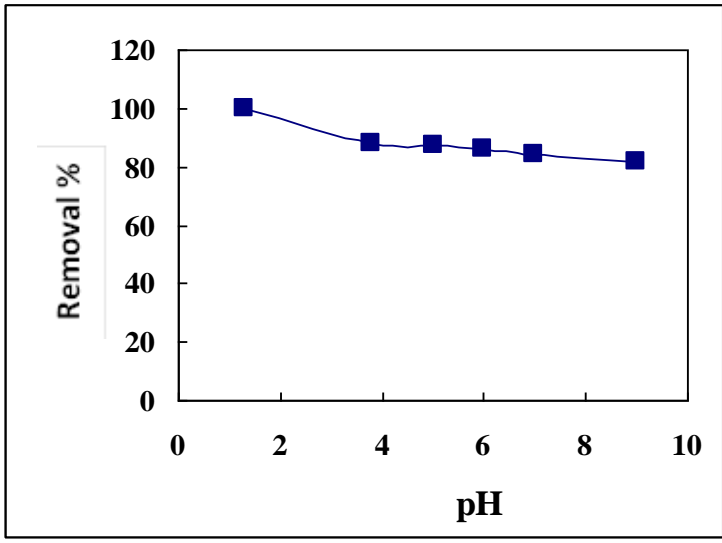

Fig.(7) Effect of pH on adsorption of CIPH at $10 \mathrm{mg} / \mathrm{L}$.

\section{Effect of Ionic Strength}

The increase in the amount of adsorbate with increase in the ionic strength of electrolyte.

$(\mathrm{NaCl})$ for the adsorbent CIPH Table (4) and Fig. (8) indicate that the adsorption is sensitive to the change in ionic Strength, which indicate that electrostatic attraction is a significant mechanism for sorption process. The increase in adsorption with ionic strength may be due to the Compression of the thickness of the diffused double layer. Such compression may help the sorbent particle and sorbate species to approach each other more closely, by then the attractive forces become significant, leading to increased adsorption. These results indicate that electrostatic attraction plays a significant role in the removal of CIP.

Table (4)

Effect of ionic strength on adsorption of CIPH at $37.5^{\circ} \mathrm{C}$.

\begin{tabular}{|c|c|c|c|c|}
\hline \multirow[b]{2}{*}{$\begin{array}{c}C_{0} \\
m g / L\end{array}$} & \multicolumn{2}{|c|}{$0.2 \mathrm{M} \mathrm{NaCl}$} & \multicolumn{2}{|c|}{$0.4 \mathrm{M} \mathrm{NaCl}$} \\
\hline & $\begin{array}{c}C_{e} \\
m g / L\end{array}$ & $\begin{array}{c}Q_{e} \\
m g / g\end{array}$ & $\begin{array}{c}C_{e} \\
m g / L\end{array}$ & $\begin{array}{c}Q_{e} \\
m g / g\end{array}$ \\
\hline 2 & 1.5527 & 0.0447 & 1.4096 & 0.0590 \\
\hline 4 & 2.0996 & 0.1950 & 1.5284 & 0.2471 \\
\hline 6 & 2.0981 & 0.3901 & 1.5939 & 0.4406 \\
\hline 8 & 2.2557 & 0.5744 & 1.7927 & 0.6207 \\
\hline 10 & 2.4618 & 0.7538 & 1.8690 & 0.8131 \\
\hline 12 & 2.5224 & 0.9477 & 1.9418 & 1.0058 \\
\hline 14 & 2.5587 & 1.1441 & 1.9406 & 1.2059 \\
\hline
\end{tabular}

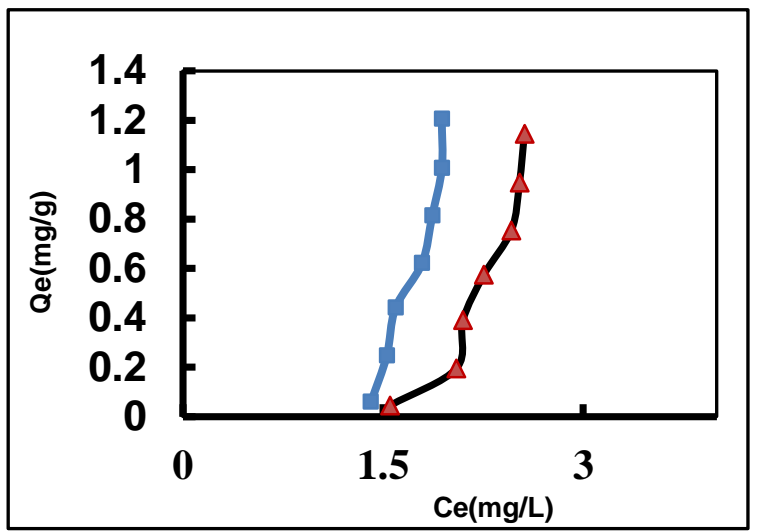

Fig. (8) Effect of ionic strength on the Adsorption CIPH on porcelinaite (a $0.4 \mathrm{M}$ and $\triangle 0.2 \mathrm{M} \mathrm{NaCl}) \mathrm{T}=37.5^{\circ} \mathrm{C}, \mathrm{pH}=3.8$ and p.size $75 \mu m$.

\section{Isotherms study}

The adsorption isotherm indicates how the adsorbed molecules distribute between the liquid phase and the solid phase when the adsorption process reaches an equilibrium state. The analysis of the isotherm data by fitting them to different isotherm models is an important step in finding a suitable model that can be used for design purpose. The adsorption capacity of this system was investigated with Freundlich and Temkin adsorption isotherms. The drug sorption isotherm followed the Freundlich model, as shown in Fig. (9). The relation between the drug uptake capacity Qe $(\mathrm{mg} / \mathrm{g})$ of adsorbent and the residual drug concentration $\mathrm{C}_{\mathrm{e}}(\mathrm{mg} / \mathrm{L})$ at equilibrium is given by 
$\log Q_{e}=\log K_{F}+(1 / n) \log C_{e}$

Where the intercept, $\log \mathrm{K}_{\mathrm{F}}$, is a measure of adsorbent capacity, and the slope $1 / \mathrm{n}$ is the sorption intensity.

The Temkin isotherm (25) is expressed as shown below.

$\mathrm{Q}_{\mathrm{e}}=\mathrm{B} \ln \mathrm{K}_{\mathrm{T}}+\mathrm{B} \ln \mathrm{C}_{\mathrm{e}}$

Where $\mathrm{K}_{\mathrm{T}}(\mathrm{L} / \mathrm{g})$ is the equilibrium binding constant, corresponding to the maximum binding energy and constant $\mathrm{B}=(\mathrm{RT} / \mathrm{b})$ is related to heat of adsorption. The Temkin isotherm plot between $\operatorname{lnC}_{e}$ and $\mathrm{Q}_{\mathrm{e}}$ is shown Fig. (10) enables the determination of the $\mathrm{B}$ and $\mathrm{K}_{\mathrm{T}}$ from the slope and intercept Table (5). These results in Table (5) show the Freundlich model was found to fit data significantly better than the Temkin show the more heterogeneous nature of Porcelinaite powder.

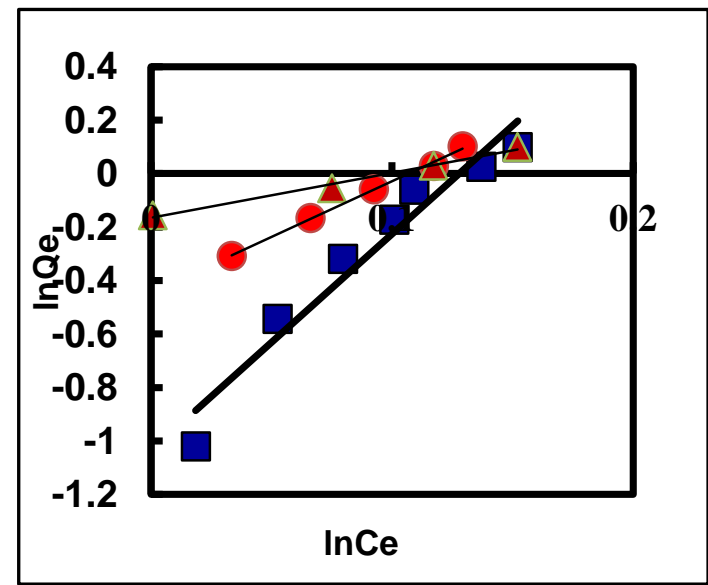

Fig.(9) Freundlich isotherm for adsorption of CIPH on Porcelinaite at different temperature $\left(15^{\circ} \mathrm{C}, \bullet 25^{\circ} \mathrm{C}\right.$ and $\left.\triangle 37.5^{\circ} \mathrm{C}\right)$.

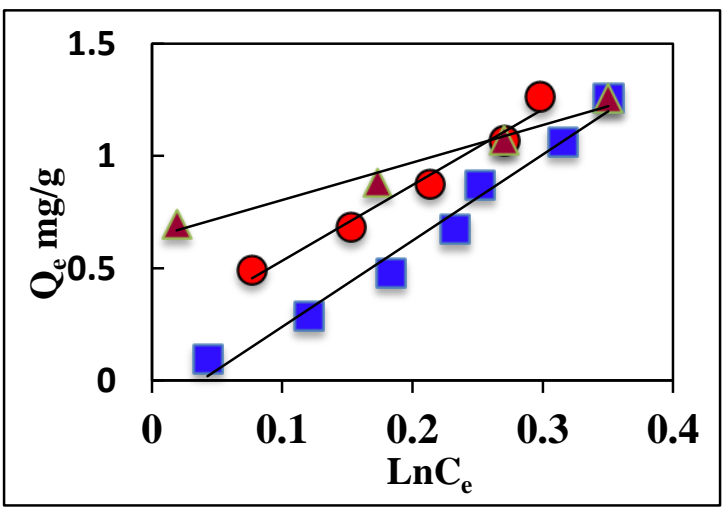

Fig.(10) Temkin isotherm for adsorption of CIPH on Porcelinaite at different temperature $\left(\square 15^{\circ} \mathrm{C}, \bullet 25^{\circ} \mathrm{C}\right.$ and $\left.\triangle 37.5^{\circ} \mathrm{C}\right)$.
Table (5)

Isotherm constants for adsorption of drug on Porcelinaite at $37.5^{\circ} \mathrm{C}$.

\begin{tabular}{|c|c|c|c|c|c|}
\hline \multicolumn{3}{|c|}{ Freundlich } & \multicolumn{3}{|c|}{ Temkin } \\
\hline \multicolumn{2}{|c|}{ constants } & \multirow{2}{*}{$\begin{array}{c}\text { Correlation } \\
\text { coefficient } \\
\left(R^{2}\right)\end{array}$} & \multicolumn{2}{|c|}{ constants } & \multirow{2}{*}{$\begin{array}{c}\text { Correlation } \\
\text { coefficient } \\
\left(R^{2}\right) \\
\end{array}$} \\
\hline$\overline{K_{f}}$ & $\bar{n}$ & & $\bar{A}$ & $\bar{B}$ & \\
\hline 1.47 & 0.59 & 0.9889 & 1.46 & 1.67 & 0.9739 \\
\hline
\end{tabular}

\section{Effect of temperature}

The effect of temperature was investigated at three different temperatures $(15,25$ and $37.5^{\circ} \mathrm{C}$ ). In present investigations, the amount of adsorption of Ciprofloxacin Hydrochloride increased with temperature increase from 15 to $37.5^{0} \mathrm{C}$ Fig. (11). Most of the adsorption processes are reported to be exothermic in nature, but present study has been found to be an example of endothermic adsorption.

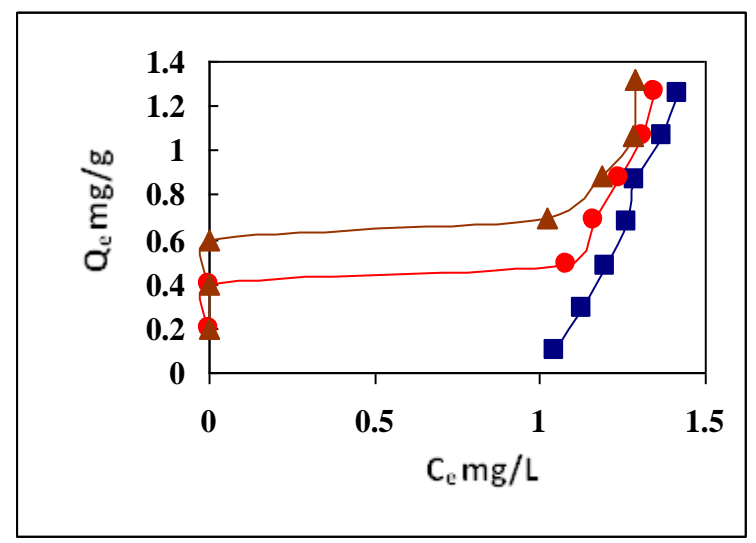

Fig.(11) Effect of temperature on adsorption

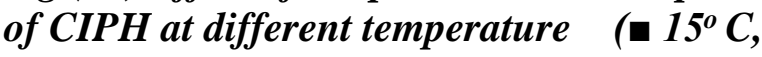
$\bullet 25^{\circ} \mathrm{C}$ and $\triangle 37.5^{\circ} \mathrm{C}$ ).

\section{Thermodynamic studies}

Thermodynamic parameters such as Gibb's free energy $(\Delta \mathrm{G})(\mathrm{J} / \mathrm{mole})$, enthalpy $(\Delta \mathrm{H})$ $(\mathrm{J} /$ mole $)$ and entropy $(\Delta \mathrm{S})(\mathrm{J} /$ mole.K) changes can be determined by the following equations:

$\Delta \mathrm{G}=-\mathrm{RT} \ln \mathrm{K}_{0}$

$\ln \mathrm{K}_{0}=-\Delta \mathrm{G} / \mathrm{RT}$

$\ln \mathrm{K}_{0}=\Delta \mathrm{S} / \mathrm{R}-\Delta \mathrm{H} / \mathrm{RT}$.

Where $\mathrm{R}$ is universal gas constant (8.314 J. mole ${ }^{-1} \cdot \mathrm{K}^{-1}$ ) and $\mathrm{T}$ is absolute temperature in Kelvin. Gibb's free energy change $\Delta \mathrm{G}$ is calculated using $\mathrm{K}_{0}$. The equilibrium constant $\mathrm{K}_{\mathrm{o}}$ can be defined as: 
$\mathrm{Ko}=\frac{\mathrm{Co}-\mathrm{Ce}}{\mathrm{Ce}}=\frac{\mathrm{Co}}{\mathrm{Ce}}-1$

The estimated thermodynamic parameter such as $\Delta \mathrm{H}, \Delta \mathrm{S}$ and $\Delta \mathrm{G}$ and equilibrium constants at each temperature are summarized in Table (6). The enthalpy change $(\Delta H)$ for the adsorption of CIPH onto Porcelinaite signifies an endothermic adsorption. The $\Delta \mathrm{G}$ value is negative at all studied temperatures, inferring that, the adsorption of CIPH onto Porcelinaite will follow a spontaneous trend. The $\Delta \mathrm{G}$ value decreased when the temperature increased from $15^{\circ} \mathrm{C}$ to $37.5^{\circ} \mathrm{C}$, suggesting increase in adsorption of $\mathrm{CIPH}$ with increasing temperature [17]. The positive value of $\Delta S$ reflects the affinity of Porcelinaite towards drug and also suggests increased randomness at the solid-solution interface.

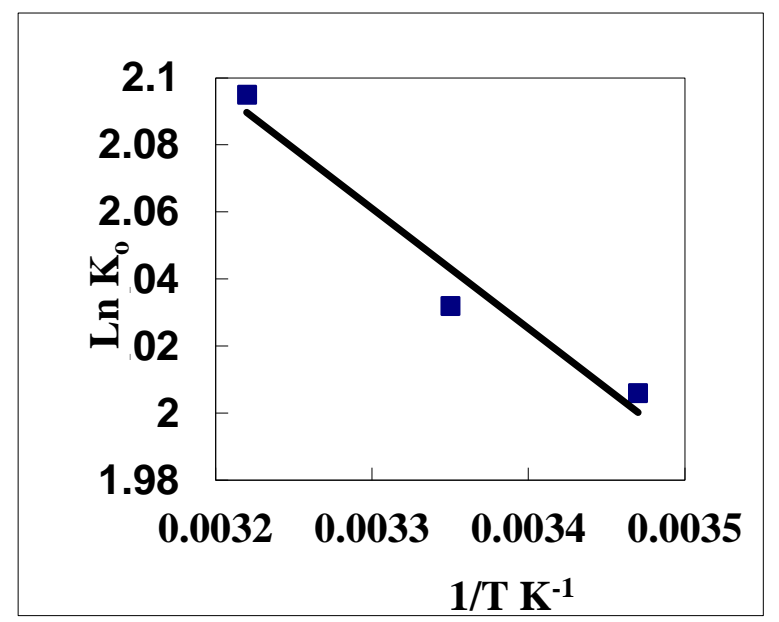

Fig.(12) Plot In Ko versus 1/ T for the estimation of thermodynamic parameters.

Table (6)

Thermodynamic parameters for CIPH adsorption on Porcelinaite.

\begin{tabular}{|c|c|c|c|c|}
\hline $\begin{array}{c}\text { Temperature } \\
{ }^{\circ} \mathrm{C} \\
\end{array}$ & $K_{o}$ & $\begin{array}{c}\Delta G K J \\
\mathrm{~mol}^{-1} \\
\end{array}$ & $\begin{array}{c}\Delta H \mathrm{KJ} \\
\mathrm{mol}^{-1} \\
\end{array}$ & $\begin{array}{c}\Delta S J \mathrm{~mol}^{-1} \\
\mathrm{~K}^{-1} \\
\end{array}$ \\
\hline 15 & 7.43 & -4.80 & \multirow{3}{*}{2.97} & \multirow{3}{*}{26.95} \\
\hline 25 & 7.63 & -5.04 & & \\
\hline 37.5 & 8.13 & -5.41 & & \\
\hline
\end{tabular}

\section{Conclusion}

Following conclusions are drawn from above discussed results:

Porcelinaite has a good adsorption capacity at $37.5{ }^{\circ} \mathrm{C}$ for the adsorption of CIPH, the percent of drug removal decrease at high concentration, equilibrium time for the adsorption of $\mathrm{CIPH}$ on porcelinaite from aqueous solutions is estimated 20 minute also the maximum adsorption of CIPH took place in the $\mathrm{pH} \mathrm{1.3,} \mathrm{the} \mathrm{maximum} \mathrm{removal} \mathrm{of} \mathrm{drug}$ $84.716 \%$ at $10 \mathrm{mg} / \mathrm{L}$ concentration was obtained with $0.1 \mathrm{~g}$ of Porcelinaite, The increase in the amount of adsorbate with increase in the ionic strength and the adsorption process of CIPH can be described by Freundlich and Temkin isotherm model.

\section{Acknowledgments}

The authors are highly thankful to the Department of Chemistry, College of Education for Pure Science Ibn Al- Haitham, University of Baghdad.

\section{References}

[1] Caliman, F. A., \& Gavrilescu, M. "Pharmaceuticals, Personal Care Products and Endocrine Disrupting Agents in the Environment"- A Review. CLEAN - Soil, Air, Water, pp 277-303, 2009.

[2] Fick, J., Söderström, H., Linderberg, R. H., Phan, C., Tysklind, M., \& Joakim Larsson, D," Contamination of Surface, Ground, and Drinking Water from Pharmaceutical Production", Environmental Toxicology and Chemistry, pp 2522-2527, 2009.

[3] Giger, W., Alder, A. C., Golet, E. M., Kohler, H.-P. E., McArdell, C. S., Molnar, E., "Occurence and Fate of Antibiotics as Trace Contaminants in Wastewaters, Sewage Sludges, and Surface Waters", Chimia 57, pp 485-491, 2003.

[4] Dror Avisar, Orna Primor, Igal Gozlan and Hadas Mamane," Sorption of Sulfonamide Tetracyclines to Montmorillonite Clay", Water Air Soil Pollut. , 209, 1-4, pp 439-450, 2010.

[5] Lee, L.; Strock, T.; Sarmah, A.; Rao, $\mathrm{P}$,"Sorption and dissipation of testosterone, estrogens, and their primary transformation products in soils and sediment", Environ. Sci. Technol, 37, pp 4098-4105, 2003. 
[6] A jaic. Hari, Rajiv A. P ar uchuri and D avid A. S abatini, "Effects of $\mathrm{pH}$ and Cationic and Nonionic Surfactants on the Adsorption of Pharmaceuticals to a Natural Aquifer Material", Environ. Sci. Technol., 39, pp 2592-2598, 2005.

[7] Kolpin, D. W.; Furlong, E. T.; Meyer, M. T.; Thurman, E. M.; Zaugg, S. D.; Barber, L. B.; Buxton, H. T, "Pharmaceuticals, hormones, and other organic wastewater contaminants in U.S. streams, 1999-2000: A national reconnaissance", Environ. Sci. Technol., 36, pp 1202-1211, 2002.

[8] Algohary O.M.N., "Invitro Adsorption of Mebeverine $\mathrm{HCl}$ onto Kaolin and its relationship to pharmacological effects of the drug Invivo", Pharm.Acta. Helve, 72, pp11-21, 1997.

[9] Chukwuenweniwe J. Ebokaand Aderemi B. Afolabi, "In-Vitro Adsorption of Fluoroquinolones on Some Pharmaceutical Adsorbents", Tropical Journal of Pharmaceutical Research, June, 5 (1), pp 533-538, 2006.

[10] Glen D. Park, PharmD; Reynold Spector, MD; Mark J. Goldberg, MD and George F. Johnson, "Expanded Role of Charcoal Therapy in the Poisoned and Overdosed Patient", Arch Intern. Med. 146(5), pp.969-973, 1986.

[11] Cassidy S.L., Hale A., Buss D.C. and Routledge P.A., "Invitro drug adsorption to charcoal, silicats, acrylate copolymer and silicon oil with charcoal and with acrylate copolymer", Hum. Exp. Toxicol. , 16 (1), pp 25-27, 1997.

[12] Algohary O. Lyall J. and Murry J.B., "Adsorption of antihypertensives by Attapulgite, charcoal, kaolin and magnesiumtrisilicate", Pham. Acta. Helv, 63, (1), pp 13-18, 1988.

[13] Reem Adham AL-Bayati," AdsorptionDesorption Isotherm of One of Antidibetic Drug from Aqueous Solutions on Some Pharmaceutical Adsorbents", European Journal of Scientific Research, 40,.4, pp.580-588, 2010.

[14] Figueroa, R. A., Leonard, A., \& Mackay, A. A, "Modeling tetracycline antibiotic sorption in clays", Environmental Science \& Technology, 38, pp 476-483, 2004.
[15] Ter Laak, T. L., Gebbink, W., \& Tolls, J., "The effect of $\mathrm{pH}$ and ionic strength on the sorption of sulfachloropyridazine, tylosin, and oxytetracycline to soil", Environmental Toxicology \& Chemistry, 25(4), pp 904-911, 2006.

[16] Omar S. Alkhazrajy, Maha A. Al-Abayaji and Mohammed H. Abdul Latif, "Adsorption of Metoclopromide Hydrochloride onto burned initiated Iraqi bentonite", journal of Alnahrain University, 15(2), pp 35-46, 2012.

[17] Isa. S.A., Jasim S.M., and Hussein H.K., "Investigation of bentonite clay surface as aphysical antidote of Amitriptyline $\mathrm{HCl}$, chlorpromazine $\mathrm{HCl}$ and Chlordizepoxide $\mathrm{HCl}$ from solution", J.Iraqi Pharm.8 (2), pp 62-68, 2002.

[18] Al-Tamimi. R.J.," Study of the ability of selected surface in adsorption of som drugs from solution", Msc. Thesis, college of Science, University of Baghdad, 2002.

[19] Rossi S, "Australian Medicines Handbook" ( $2^{\text {nd }}$ ed). Adelaide, 2006.

[20] Carabineiro A, Thavorn-Amornsri T, Pereira F, Figueiredo L.," Adsorption of ciprofloxacin on surface-modified carbon materials", Water Res. 1;45 (15), pp. 4583-91, 2011.

[21] Chih-Jen W, Zhaohui L, Wei-Teh J, "Adsorption of ciprofloxacin on 2:1 dioctahedral clay minerals", Applied Clay Science ,53,4, pp723-728, 2011.

[22] Ibezim EC, Ofoefule SI, Ejeahalaka N, Orisakwe E., "In vitro adsorption of ciprofloxacin on activated charcoal and Talc". Am J Ther., 6(4), pp 199-201, 1999.

[23] Franceline $R$, Nicolas $T$, Michel $D$, Tibiriça G. V, Claire G, Sílvia S. G , Adriana R. P and Elias F, "Spray-dried chitosan-metal microparticles for ciprofloxacin adsorption: Kinetic and equilibrium studies", Soft Matter, 7, pp. 7304-7312, 2011.

[24] Avisar, D., Lester, Y., \& Mamane, H., "pH induced polychromatic UV treatment for the removal of a mixture of SMX, OTC and CIP from water", Journal of Hazardous Materials, 175(3-1), pp.10681074, 2010. 
[25] Ejikeme P. M, A. I. Okoye and O. D.Onukwuli, "Kinetics and Isotherm Studies of $\mathrm{Cu}^{2+}$ and $\mathrm{Pb}^{2+}$ Ions Removal from Simulated Waste Water by Gambeya Albida Seed Shell Activated Carbon", The African Review of Physics, 6, pp143-152, 2011.

$$
\begin{aligned}
& \text { الخلاصة } \\
& \text { تعد المستحضرات الصبدلاثية من المركبات ذات } \\
& \text { الاستعمال الواسع والتي من الممكن ان تتنشر في البيئة. في مئ } \\
& \text { هذا البحث تمت دراسة امتزاز عقار السييروفلوكساسين } \\
& \text { هيدروكلورايد على سطح ماز هو البورسيلاين العراقي عند } \\
& \text { ظروف محددة ولوحظ من خلال الدراسة ان ايزوثيرمات } \\
& \text { الامتزاز تتبع كل من معادلة فريندلش وتمكن على التوالي كما } \\
& \text { تم دراسة تاثثر الاس الهيدروجيني على قابلية الامتزاز عند } \\
& \text { مدى من r, ا-9 كما تم ايضا دراسة تاثير الثدة الايونية } \\
& \text { على عملية الامتزاز كما تم ايضا دراسة الانثالبي لعملية } \\
& \text { الامتزلز حيث اوجدت القيم ان العملية تعتبر ماصة للحرارة }
\end{aligned}
$$

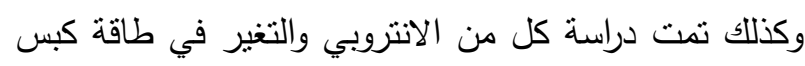

$$
\begin{aligned}
& \text { وعند درجات حرارية متعددة. }
\end{aligned}
$$

